\title{
Planning and Implementing a Program for Upgrading Nurses Knowledge about Emergency Contraceptive Pills in Port Said City
}

\author{
Sanaa Ali Nour, Hadayat Abdel-Raouf Amasha, Manar Fathy Heeba, \\ Esraa Mostafa Abdel Aty Ebrahim
}

Prof. of Obst.\&Gyne. Nursing, Faculty of Nursing, Zagazig University Assistant Prof. of Maternity, Obst. \&Gyne. Nursing, Faculty of Nursing, Port Said University; Dr. Maternity, Obst. \&Gyne. Nursing, Faculty of Nursing, Port Said University; Assistant lecture of Maternity, Obst. \&Gyne. Nursing, Faculty of Nursing, Port Said University;

\begin{abstract}
Background: Emergency contraceptive pills (ECPs) are important resource with excellent potential to further reduce the number of unwanted pregnancy and abortion. Therefore, this study.Aim: aims to assess and evaluate the impact of an educational program on nurse's knowledge toward using ECPs. Subjects and methods: a quasiexperimental intervention study for nurses were used in this study. 27 maternity nurses were selected convenience for the intervention part of this study. The data were collected through the period of seven months. The researcher used self-administrated questionnaire tools for the nurses.Results: The results revealed that: nurses had deficient knowledge on ECPs $(7.4 \%)$ at the pre-program phase while after implementation of nursing educational program there are a statistically significant improvement in nurse's knowledge at post and follow-up phases was showed. Conclusion: significant improvement of nurse's knowledge was shown after the implementation of the educational program. Recommendations: family planning counseling by the maternity nurse including ECPs must be emphasized as an integral part of any family planning activities and programs, continuous refreshing courses about ECPs for nurses including the newly appointed nurses as well as regular supervision and evaluation of nurse's performance. On the other hand, hotlines should be developed to provide information about emergency contraceptives and referrals to clinics that provide these services.
\end{abstract}

Key Words: Planning, Implementing, Program, Emergency contraceptive pills, Nurse's knowledge. 


\section{INTRODUCTION}

Unintended pregnancy is a global problem Fathalla et al.,( 2003). Nearly 4 in 10 pregnancies around the globe are unplanned and about 2 in 10 ends in abortion Trussell\& Wynn,( 2008). In addition to, their negative social impact, may lead some women to seek induced abortion, a procedure which in settings (like Egypt) where abortion is illegal is often unsafe Shah\&Ahman, (2009). Unintended pregnancy which continues to childbirth is often associated with delay in initiation of prenatal care and with shorter interpregnancy intervals and may negatively influence child health, development and survival U.S. Department of Health and Human Services, (2013).

The lack use of contraceptives and the lack of knowledge about the proper use of contraceptives are the major reasons for unintended pregnancy. The Alan Guttermacher Institute (AGI) (2014) noted that there are 62 million U.S. women in their childbearing years (15-44). There are about 43 million of them (70\%) are at risk of unintended pregnancy that is, they are sexually active and do not want to become pregnant, but could become pregnant if they and their partners fail to use a contraceptive method correctly and consistently. Most of the women 62\% of reproductive age are currently using a contraceptive method. However, only 11 percent of women at risk of unintended pregnancy are not currently using any contraceptive method Joneset al., (2013).

Emergency contraceptive (EC) reduce the need for induced abortion and related complexities. Knowledge of EC would protect a large number of women's from trauma of induced abortion, as well as reduce morbidities and mortalities and pregnancy complications Sebastian et al.,( 2005). Available literature suggest that ECP that contains higher doses of the hormones used in oral contraceptive pills is the term given to methods of contraception that can be used by women following unprotected vaginal sex to prevent an unplanned pregnancy Trussel\& Raymond, (2010). And ECP should be used within 120 hours of unprotected sexual relation, preferably with 72 hours and they could back up for lactational amenorrhea method of contraception until other more effective method is used Hossain, (2009).

Sue, (2009) stated that, there are two types of emergency contraceptive pills. Combined (Yuzpe regimen) containing both estrogen and progestin, and progestinonly pills. The newer progestin-only emergency contraceptive pills have now largely replaced the older combined emergency contraceptive pills because they are more effective and cause fewer side effects. ECPs may be initiated sooner after immediately unprotected intercourseTrussell\& Raymond,( 2007). The first dose of emergency contraceptive pill should be as soon as possible after unprotected intercourse, and the second dose following the first dose by 12 hours later Brunton\& Beal, (2006).

The mode of action of hormonal emergency contraceptive pill is through three ways to prevent pregnancy. There are namely delaying ovulation, preventing fertilization, or preventing implantation of a fertilized egg. The method of action depends on the part of the menstrual cycle and the time of unprotected intercourse. Nonetheless, 
emergency contraceptive pills do not act as abortifacients, and will not harm or cause teratogenic effects to an existing pregnancy.

Furthermore, Nurses at all levels are often the first point of contact for a woman who is requesting emergency contraceptive. Thus, it is particularly important for them to be abreast of both the facts regarding the use of (ECPs) and the current political controversies Clements \& Daley, (2006). They need to be knowledgeable and available to provide accurate information and change women misconceptions about emergency contraceptive pills, which brand of pills, the estimated effectiveness rates, possible side effects and how to manage them.

\section{AIM OF THE STUDY:}

Assess and evaluate the impact of an educational program on nurse's knowledge toward using ECPs.

\section{Research hypothesis}

The level of nurse's knowledge will be improved after attending the educational program regarding emergency contraceptive pills.

\section{SUBJECTS AND METHODS:}

Research design: A quasi-experimental intervention study with pre-post assessment to evaluate the effect of the educational program on nurse's knowledge toward LAM and ECPs

Study setting :the study was carried out in fourteen primary health care centers representing the six districts of Port-said, namely: : Port-fouad first, Bank elescan, Port-fouad second, El manakh first, El Kuwait, El arab first, Fatmaelzahraa, Omar EbnElkhatab, El abouty, Osman EbnAfan, Mostafakamel, El gawhara, El arab child care and El manakh child care.

Subjects: the subject of the study included all nurses (27) working in the above mentioned settings, who are willing to participate in the program.

\section{Tools for data collection:}

\section{Self-administrated questionnaire for the nurse:}

This questionnaire sheet was developed based on (Shama, 2012) and (Sharawy, 2014). It includes: -

\section{First part:}

Socio-demographic data as (age, marital status, education level, years of experience and training courses...etc).

\section{Second part:}

Knowledge questionnaire to assess nurse's knowledge as regard:

- Emergency contraceptive pills as: (definition, types, component, and mode of action, indications, contraindications, effectiveness, and adverse reactions). 


\section{Third part:}

Program booklet: Summary for the educational program that was prepared for nurses to improve their knowledge. A booklet included information about importance of ECPs such as: (definition of ECPs, components,types, mode of action, indication, efficacy, and time of use, mode of use, side effects and contraindication were all included). Pre and post test questions related to nurse's knowledge were utilized using questionnaire sheet.

Scoring: For the knowledge items, a correct response was scored 1 and the incorrect response takes zero. The items were summed up and the total divided by the number of the items, giving a mean score for the part. These scores were converted into a percent score, means and standard deviations were computed. Knowledge was considered satisfactory if the percent scores at $60 \%$ or more and unsatisfactory if less than $60 \%$.

\section{Methods of study:}

- An official letter from the dean of the faculty of nursing was sent to the director of the selected area of the study. The director of each clinic was contacted and informed in order to obtain permission to include the nurses on the present research.

- The tools used in data collection were reviewed by a jury of 10 experts in the field of obstetrics and gynecological nursing and medicine field to ascertain their content validity.

- Informed consent was obtained from each nurse in the study after explaining its purpose and importance. Confidentially of the obtained information was assured by the researcher.

- A pilot study was carried out over a period of two months. It was conducted on $10 \%$ of total sample size involving nurses to evaluate the content validity, time required to fill each tool and feasibility of tools of the study. Necessary modifications were carried out as revealed from the pilot study.

- The actual study was conducted through four phases: assessment phase, program development phase, implementation phase and evaluation phase as follows :

\section{Assessment phase:}

A pretest self-administered questionnaire was used to assess nurse's knowledge about ECPs. This was also used for the posttest.

\section{Implementation phase of the program:}

After the assessment phase was done for nurse the researcher started to implement the program sessions for the intervention group. The researcher was available six days / week in the study settings alternatively according to table 1 to conduct the program

The total number of sessions was nine sessions for theoretical knowledge, each session took about two hours. The attended numbers of nurses in each session were between two to three nurses. The topics of theory sessions included (about 
definition of ECPs,components, types, mode of action, indication, efficacy, and time of use, mode of use, side effect and contraindication were all included). Methods of teaching used included modified lectures and group discussion. Suitable teaching aids were used including, power point presentation, pamphlet and handout.

\section{Evaluation phase:}

After the completion of the program, the post-test was done immediately after the program using the pre/post-test questionnaire to assess the nurse knowledge. A follow up evaluation was also done after three months to find out the retention of the information given.

\section{Statistical analysis of data:}

Up completion of data collection, variables included in the structured interview sheet, were coded prior to computerized data entry. The raw data were coded and transformed into coding sheets. The results were checked. Then, the data were entered using SPSS 20.0 statistical software package. Output drafts were checked against the revised coded data for typing and spelling mistakes. Finally, analysis and interpretation of data were conducted.

\section{RESULTS:}

Table( 1): revealed the distribution of the studied nurses according to their sociodemographic characteristic. Their age ranged between $25-52$ years with a mean age of $37.9 \pm 7.3$ with the highest percentage $(48.1 \%)$ was between $30-40$ years. The great majority (96.3\%) completed their nursing diploma and was married. Meanwhile, more than half of them $(55.6 \%)$ had 5-15 years of experience.

Table (2): illustrates the distribution of the studied nurses according to their previous training in the field of family planning about ECPs. All nurses received training in the field of family planning, the majority received training from an educational programs conducted in the primary health centers $(70.4 \%)$, however, almost two fifths (40.7\%) of them who advised their clients to take ECPs as a backup for LAM.

Table ( 3): shows that statistically significant improvement was revealed at both the post and follow-up phases in all area of tested knowledge $(\mathrm{p}<0.001)$ except the knowledge about effectiveness, criteria, definition and types of LAM. At the followup, only knowledge about the criteria and types of LAM did not decline. Although, all the other areas have demonstrated some decline but still were statistically significant higher than the pre- program levels.

Figure (1): points to statistically significant improvement that was revealed at both the post and follow-up phases. Despite the fact that $11.1 \%$ of nurses had unsatisfactory knowledge at the follow up, the level at the follow-up phase was still statistically significant higher than the pre- program levels. 
Table (1): Distribution of the Studied Nurses According to their SocioDemographic Characteristics. $\mathrm{N}=27$.

\begin{tabular}{|l|c|c|}
\hline \multicolumn{1}{|c|}{ Socio-demographic characteristics } & \multicolumn{2}{c|}{$\begin{array}{c}\text { Studied } \\
\text { nurses } \\
\text { (n=27) }\end{array}$} \\
\cline { 2 - 4 } & No. & \% \\
\hline Age (years) & & \\
$<30$ & 4 & 18.5 \\
$30-40$ & 13 & 48.2 \\
$>40$ & 9 & 33.3 \\
\hline Min-Max & $25.0-52.0$ \\
Mean \pm SD & $37.9 \pm 7.3$ \\
\hline Marital status & & \\
Married & 26 & 96.3 \\
Widow & 1 & 3.7 \\
\hline Educational qualifications & & \\
Nursing Diploma & 26 & 96.3 \\
Nursing institute & 1 & 3.7 \\
\hline Duration of nursing experience in FP & & \\
Less than 5 Year & 8 & 29.6 \\
5-15 Year & 15 & 55.6 \\
16-30 Year & 4 & 14.8 \\
\hline
\end{tabular}

Table (2) : Distribution of the Studied Nurses According to Previous Training in the Field of Family Planning about ECPs $(n=27)$

\begin{tabular}{|l|c|c|}
\hline \multicolumn{1}{|c|}{ Previous Training } & \multicolumn{2}{c|}{$\begin{array}{c}\text { Studied } \\
\text { nurses } \\
\text { (n=27) }\end{array}$} \\
\cline { 2 - 3 } & No. & $\%$ \\
\hline Previous training on FP & & \\
No & 0 & 0.0 \\
Yes & 27 & 100.0 \\
\hline Previous training on ECPs & & \\
No & 0 & 0.0 \\
Yes & 27 & 100.0 \\
\hline Source of knowledge about ECPs & & \\
School/institute & 2 & 7.4 \\
Readings & 2 & 7.4 \\
Colleagues & 4 & 14.8 \\
Training & 19 & 70.4 \\
\hline Advised women to take ECPs as a backup for LAM & & \\
Yes & 11 & 40.7 \\
No & 16 & 59.3 \\
\hline
\end{tabular}


Table (3) : Distribution of Nurses According to Satisfactory Knowledge about ECPs throughout the Program Phases ( $n=27)$.

\begin{tabular}{|c|c|c|c|c|c|c|c|c|}
\hline \multirow{3}{*}{ Areas of knowledge } & \multicolumn{6}{|c|}{$\begin{array}{l}\text { Satisfactory knowledge of nurses } \\
(n=27)\end{array}$} & \multirow{3}{*}{ Sig1 } & \multirow{3}{*}{ Sig2 } \\
\hline & \multicolumn{2}{|c|}{ Before } & \multicolumn{2}{|c|}{ After } & \multicolumn{2}{|c|}{ Follow up } & & \\
\hline & No. & $\%$ & No. & $\%$ & No. & $\%$ & & \\
\hline Definition of ECPs & 26 & 96.3 & 26 & 96.3 & 25 & 92.6 & 1.0 & 1.0 \\
\hline Components of ECPs & 3 & 11.1 & 21 & 77.8 & 14 & 51.9 & $<0.0001^{*}$ & $0.007 *$ \\
\hline Types of ECPs & 24 & 88.9 & 27 & 100.0 & 27 & 100.0 & 0.25 & 0.25 \\
\hline Mode of action of ECPs & 4 & 14.8 & 24 & 88.9 & 17 & 63.0 & $<0.0001 *$ & $<0.0001^{*}$ \\
\hline Indications of ECPs & 8 & 29.6 & 26 & 96.3 & 23 & 85.2 & $<0.0001 *$ & $<0.0001^{*}$ \\
\hline Time of ECPs & 10 & 37.0 & 24 & 88.9 & 23 & 85.2 & $<0.0001^{*}$ & $<0.0001^{*}$ \\
\hline Mode of use of ECPs & 0 & 0.0 & 23 & 85.2 & 18 & 66.7 & $<0.0001^{*}$ & $<0.0001^{*}$ \\
\hline Effect of ECPs & 4 & 14.8 & 26 & 96.3 & 19 & 70.4 & $<0.0001 *$ & $0.001 *$ \\
\hline Side effects of ECPs & 6 & 22.2 & 25 & 92.6 & 15 & 55.6 & $<0.0001^{*}$ & $0.022 *$ \\
\hline Contraindications of ECPs & 10 & 37.0 & 24 & 88.9 & 21 & 77.8 & $0.001 *$ & $0.001 *$ \\
\hline
\end{tabular}

Figure (1) : Nurses' total Knowledge about ECPs throughout the Program phases $(n=27)$

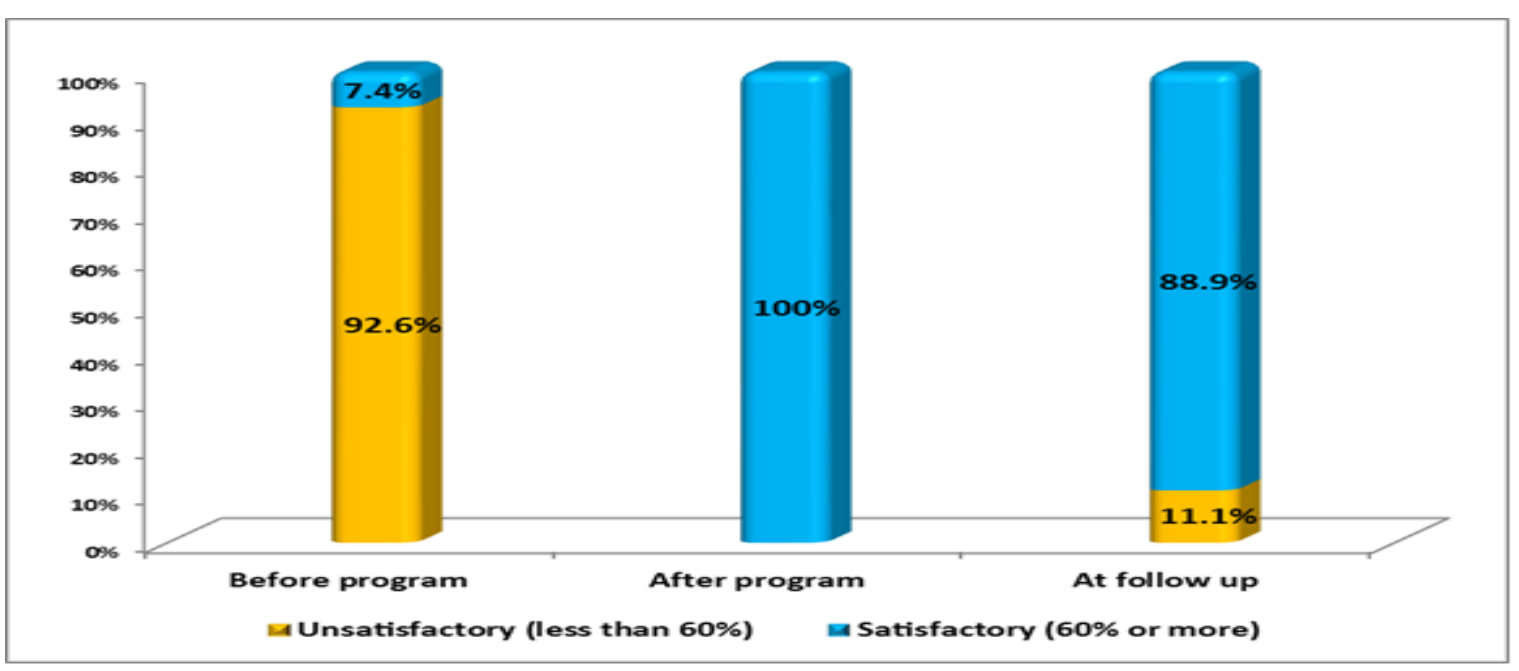

\section{DISCUSSION:}

The current study finding has shown that despite the fact that all nurses were aware about ECPs; their baseline knowledge about it was very low. Thus, at the preplanning phase of the educational program, none of the nurses had a satisfactory knowledge about the component of the EC pills, mode of action, indication, time, mode of use, effect, side effect as well as contraindication. These findings are in agreement with Sharawy, (2014) and Zaghaloul, (2011) they have similarly documented poor knowledge among nurses about ECPs. This might be attributed to 
the fact that ECPs is a relatively new method, less commonly advised by the physicians, and there is less stress about it in nursing curriculum and ongoing training. Moreover, Egyptian mass media do not provide enough propaganda about it.

Although, the meeting held by the international Planned Parenthood Federation (IPPF), Family Health International (FHI), Population Council and WHO at Bellagio developed a consensus statement calling for the need to make access to EC a practical reality. Shortly afterwards, the Consortium for EC, an international collaboration of seven organizations, was created. The promotion of the concept of emergency contraception by this Consortium gave a totally new life to this method Faundes $\boldsymbol{e t}$ al.,(2007). Furthermore, ECPs were added to the WHO list of essential drugs, making them much more readily available in different countries Zaghaloul,(2011).

The result of the present study has shown that the training program developed and implemented for nurses was successful in improving their knowledge regarding ECPs. Hence, at the post-test, all the study nurses had satisfactory knowledge. However, some decline was revealed at the three months follow-up, which was most obvious in knowledge. Nonetheless, the level at the follow-up was still significantly higher, compared to the pre-program levels. Thus there is a need for booster session for the nurses to retain the acquired gains from the program. These findings are agreed with those of the study conducted by Sharawy, (2014) and Zaghaloul, (2011)which almost have the same results.

The WHO recommended that effective contraceptive services required providers with technical training in the correct nurses' performance and timely administration of the methods. In addition, it may require a special efforts to encourage positive attitude and practice toward EC among the providers Zaghaloul, (2011). However, Schiappacasse \& Diaz, (2006) emphasized the fact that, the lack of knowledge among providers, program manager, and policy makers is an obstacle to the introduction of ECPs in reproductive health programs. They may not have a clear understanding of the role that ECPs can play in improving the reproductive health of women, or they may be reluctant to provide EC since they have insufficient training in the procedure involved.

\section{CONCLUSION:}

\section{Based on the findings of the present study, it can be concluded that:}

Nurses showed knowledge deficit regarding ECPs at the pre-planning phase of the educational program. Implementation of the educational program was associated with statistically significant improvements in nurse's knowledge regarding ECPs. However, some decline was revealed at the three months follow-up.. Totally, the knowledge level at the follow-up phase was still significantly higher compared to the pre-program levels. 


\section{RECOMMENDATIONS:}

\section{The study recommended the following:}

- Family planning counseling by the maternity nurse including ECPs must be emphasized as an integral part of any family planning activities and programs.

- Continuous refreshing courses about ECPs for nurses including the newly appointed nurses as well as regular supervision and evaluation of nurse's performance. This is essential to upgrade their knowledge and practice concerning all contraceptive methods.

- Replication of the present study on a larger scale including all of the available districts in Port-Said to validate the study findings.

\section{REFERENCES:}

Brunton J., Beal M.(2006): Current issues in emergency contraception: An overview for provider. Journal of Midwifery and Women's health; 51:(6):451-463.

Clements A., Daley A. (2006): Emergency contraceptive pills: A primer for pediatric providers, Pediatric Nursing; 32(2):147-153.

Fathalla M.F., Abdel-Raheem M.S., Amin A. (2003): The prevalence, determinants and outcome of unintended pregnancy: a hospital-based study. Egypt SocObstetGynecol; 29:945-54.

Faundes A., Tavara L., Brachefc V., Alvarez F. (2007): Emergency Contraception under Attack in Latin America: Response of the Medical Establishment and Civil Society. Reproductive Health Matters 2007; 15(29): pp. 130-138.

Hossain S.M.I. (2009): ECP handbook: Introducing and mainstreaming the provision of emergency contraceptive pills in developing countries, FRONTIERS Manual. Washington, DC: Population Counsil.

Jones J., Mosher W.D., Daniels K. (2013): Current contraceptive use in the United States, 2006-2010, and changes in patterns of use since 1995, National Health Statistics Reports, 2012, No. 60, <http://www.cdc.gov/nchs/data/nhsr/nhsr060.pdf>.

Schiappacasse V., Diaz S. (2006): Access to emergency contraception. Int J Gynecol\&Obstet, 94: pp. 301-309. 
Sebastian M.P., Khan M.E., Kummar S., Shekhar C., Gputa N. K. (2005): Study the use of emergency contraceptive services through paramedics in India. Research Update No. 5, New Delhi: Population Counsil/FRONTIERS.

Shaaban O.M., Hassen S.G., Nour S.A., Kames M.A., Yones E.M. (2013): Emergency contraceptive pills as a backup for lactational amenorrhea method (LAM) of contraception: a randomized controlled trial, Elsevier Inc; 7929:1-7.

Shah I., Ahman E. (2009): Unsafe abortion: global and regional incidence, trends, consequences, and challenges. J ObstetGynaecol Can; 31: 1149-58.

Shame E.E.A. (2012): Planning and Implementing A program for Upgrading Nurses Knowledge and Attitude about Emergency Contraceptive Pills in Port Said, Doctoral Thesis, Faculty of Nursing, Port Said university: pp.153- 174.

Sharawy H.R.M.R. (2014): Utilization Of Emergency Contraceptive Pills To Support Lactational Amenorrhea , Doctoral Thesis, Faculty Of Nursing, Zagazig university: pp.85- 98 .

Sue A. (2009): Emergency Contraceptive Pills: The Word from Medical Professionals, Advocates for Youth, Washington DC 20036 USA; pp. 1-6.

The Alan Guttmacher Institute (AGI) (2014): Contraceptive Use in the United States, New York.

TrussellJ., and Raymond. (2007): Emergency contraception: A Cost Effective Approach to preventing unintended pregnancy; 9:446.

Trussell J., Raymond E.G. (2010): Emergency contraception: A last chance to prevent unintended pregnancy. Available at URL: www.not-2-late.com.

Trussell J., Wynn L.L. (2008): Reducing unintended pregnancy in the United States. Contraception; 77:1-5.

U.S. Department of Health and Human Services (2013): Child Health USA, Health Resources and Services Administration, Maternal and Child Health Bureau: 21-23. 
Zaghaloul M.G. (2011): Effectiveness of an Educational training program about emergency contraceptive pills on nurse's knowledge and performance. Egyptian Journal of Nursing (EJN): pp. 13-26. 


\section{تخطيط وتتفيذ برنامج لتحسين معلومات الممرضات عن حبوب منع الحمل فى الحالات الطارئة بيورسعيا}

سناء على نور ،ا مد هديات عبد الرؤوف عماثة ، منار فتحى هيبه ، أسر اء مصفطى عبد العاطى استاذ تمريض نساء وتوليد كليه تمريض جامعه الزقازيق "ا ستاذ مساعد تمريض الامومده و النساء و التوليدـ كليه

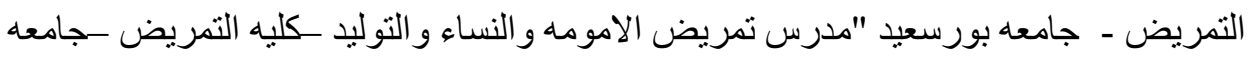

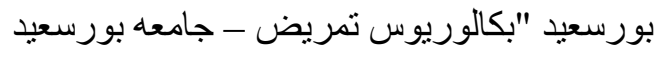

\section{الـخـلاصــة}

يعتبر توفير وسائل منع الحمل للحالات الطارئة من أهم الخطوات التى يمكن اللجوء إليها لتجنب حدوث الحمل الغير مرغوب فيه مما قد يعرض السيدات لمشاكل الحمل و الولادة أو الحاجة للتخلص منه عن طريق الإجهاض. ولهذا السبب نهذف هذه الدراسة إلى تقييم تأثير فعالية برنامج تعليمي على معلومات الممرضات تجاه استخدام حبوب منع الحمل الطارئة. وقد إستخدمت الدراسة الثبة تجريبية للممرضات. و وإنتملت عينة البحث على 27 ممرضه من اللاتى يعملن فى عيادات تنظيم الأسرة فى مراكز الرعاية الصحية الأولية ببورسعيد. وتم تجميع البيانات خلال سبعة أنشهر بإستخدم إستمارة إستبيان خاصة بالممرضات لتقييم معلوماتهم و وقد كثفت نتائج الدراسة على أن هناك نقص واضح فى معلومات الممرضات تجاه حبوب منع الحمل الطارئة ، وكان لتطبيق البرنامج التعليمى للممرضات أثره الو اضح فى تحسين معلوماتهن. استنادا إلى هذه النتائج يمكن أن نستخلص من ذلك أن: تطبيق البرنامج التعليمى للممرضات كان له أثر واضح و ملحوظ فى تحسين معلومات الممرضات. لذلك توصى هذه الدراسة بأن الممرضات بحاجة للتاكيد عليهن بأن حبوب منع الحمل

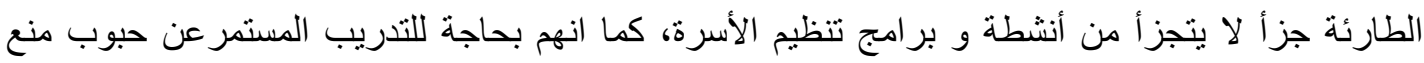

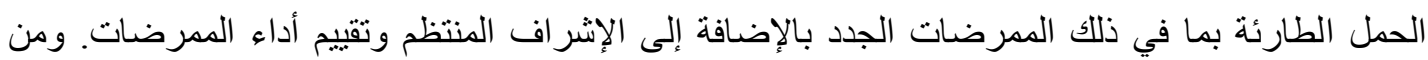
ناحية أخرى ينبغي وضع خطوط ساخنة لتقيم المعلومات للسيدات حول وسائل منع الحمل الطارئة وكذلك اللك الإحالة إلى العيادات التي توفر هذه الخدمات.

الكلمات الدالة: تخطبط - تنفيذ- برنامج تدريبى - وسائل منع الحمل الطارئة ـ معلومات المدرضات. 